\title{
PENGARUH SUHU PENETASAN TERHADAP FERTILITAS, MORTALITAS DAN DAYA TETAS TELUR AYAM KAMPUNG (Gallus domesticus) PADA INKUBATOR
}

\author{
Yuni Mariani $^{1 *}$, Ni Made Andry Kartika ${ }^{2}$, M. Ayatullah Hamzani ${ }^{3}$ \\ 1,2,3 Program Studi Peternakan, Universitas Nahdlatul Wathan Mataram, Indonesia \\ *Email: mariani.yuni25@gmail.com
}

Diterima: 15 Februari 2021. Disetujui: 30 Maret 2021. Dipublikasikan: 26 April 2021

\begin{abstract}
ABSTRAK
Penelitian ini dimaksudkan untuk mengetahui suhu terbaik penetasan telur ayamkampung pada inkubator sehingga peternak bisa mendapatkan day old chicken (DOC) dalam jumlah yang lebih banyak dengan keragaman yang sama. Rancangan penelitian ini menggunakan Rancangan Acak Lengkap (RAL). Penelitian ini menggunakan 150 butir telur ayam kampung yang didapat dari para peternak yang ada di Dusun Gunung Paok Desa Perian Kecamatan Montong Gading Kabupaten Lombok Timur yang dibagi menjadi 3 perlakuan yaitu $35^{\circ} \mathrm{C}-36^{\circ} \mathrm{C}, 37^{\circ} \mathrm{C}-38^{\circ} \mathrm{C}$ dan $39^{\circ} \mathrm{C}-40^{\circ} \mathrm{C}$ dan 5 ulangan dengan jmlah telur perulangan menggunakan 10 butir telur ayam kampung. Variabel yang di amati ialah fertilitas, mortalitas dan daya tetas telur ayam kampung. Analisis data dilakukan dengan menggunakan Analysis of Variance (ANOVA). Hasil analisa sidik ragam menunjukkan bahwa perbedaan suhu telur ayam kampung pada inkubator menunjukkan perbedaan yang nyata $(\mathrm{P}>0,05)$ terhadap fertilitas, mortalitas dan daya tetas. Hasil terbaik diperoleh pada suhu inkubasi $37^{\circ} \mathrm{C}-38^{\circ} \mathrm{C}$ dengan rata-rata daya tetas $82,88 \pm 8,87 \%$.
\end{abstract}

Kata kunci: Suhu, Fertilitas, Mortalitas, Daya Tetas, Telur Ayam Kampung.

\begin{abstract}
This study was intended to determine the best temperature for hatching free-range chicken eggs in the incubator so that breeders could get more day-old chicken (DOC) with the same diversity. The research design used a completely randomized design (CRD). This study used 150 free-range chicken eggs obtained from breeders in Gunung Paok Hamlet, Perian Village, Montong Gading District, East Lombok Regency, which were divided into three treatments, namely $35^{\circ} \mathrm{C}-36^{\circ} \mathrm{C}, 37^{\circ} \mathrm{C}-38^{\circ} \mathrm{C}$ and $39 .{ }^{\circ} \mathrm{C}-40^{\circ} \mathrm{C}$ and five repetitions with the number of eggs repeating using 10 free-range chicken eggs. The variables observed were fertility, mortality, and hatchability of native chicken eggs. Data analysis was performed using Analysis of Variance (ANOVA). The results of the analysis of variance showed that differences in the temperature of native chicken eggs in the incubator showed a significant difference $(\mathrm{P}>0.05)$ in fertility, mortality, and hatchability. The best results were obtained at an incubation temperature of $37^{\circ} \mathrm{C}-38^{\circ} \mathrm{C}$ with an average hatchability of $82,88 \pm 8,87 \%$.
\end{abstract}

Keywords: Temperature, Fertility, Mortality, Hatchability, Chicken Eggs.

\section{PENDAHULUAN}

Ayam Kampung (Gallus domesticus) adalah jenis unggas ternak ras lokal yang banyak di pelihara oleh banyak orang. Selain diambil dagingnya ayam kampung juga diternakan untuk di ambil telurnya. Ayam kampung biasanya banyak kita jumpai berkeliaran bebas di pekarangan rumah warga maupun perkebunan masyarakat pedesaan pada umumnya, namun tidak bisa kita pungkiri dengan semakin berkembangnya zaman dan semakin bertambahnya kebutuhan manusia akan kebutuhan hewani. Konsumsi protein masyarakat Indonesia mencapai 62,11 gram/kapita/hari pada tahun 2017 dan mengalami peningkatan menjadi 64 gram/kapita/hari pada tahun 2018 (BPS, 2019).

Masyarakat semakin menyadari akan pentingnya protein hewani bagi pertumbuhan tubuh. Hal ini mengharuskan tetap tersedianya pangan sumber protein hewani untuk memenuhi kebutuhan masyarakat. Salah satu komoditas yang berpotensi untuk di kembangkan sebagai sumber protein hewani adalah ternak ayam kampung (Gallus domesticus)

Ayam kampung merupakan salah satu jenis unggas yang banyak terdapat di Indonesia. Ayam kampung memiliki potensi yang besar untuk di kembangkan sebagai penghasil telur maupun daging. Ayam Kampung sangat menjanjikan untuk dibudidayakan, selain dari segi penanganannya yang terbilang cukup mudah untuk di jalankan baik dalam sekala kecil maupun besar, cita rasa ayam kampung juga sangat berbeda dari ayam ras lainnya, sehingga banyak kita jumpai rumah makan yang ada di pinggir jalan menyediakan menu Ayam Taliwang yang memang murni ayam kampung asli khas Indonesia. 
Perkembangan usaha budidaya ternak ayam kampung sebagai penghasil daging dan telur mempunyai hambatan dalam penyediaan bibit. Untuk memperoleh bibit yang banyak dengan keragaman yang sama dan untuk memenuhi kebutuhan masyarakat baik dari konsumen maupun peternak maka perlu dilakukan pembiakan secara komersial menggunakan mesin penetas buatan. Penetasan merupakan rekayasa pengeraman menggunkan mesin tetas dengan cara menyediakan lingkungan yang sesuai untuk embrio telur sehingga dapat berkembang dengan optimal dan telur dapat menetas. Penetas buatan lebih praktis dan efisien dibandingkan dengan penetasan alami dengan kapasitas yang lebih besar. Penetasan dengan mesin tetas juga dapat meningkatkan skala produksi dan daya tetas telur karena aspek lingkungan yang dibutuhkan dalam proses penetasan seperti suhu dan kelembaban dapat di atur secara tepat. Pada dasarnya prinsip kerja mesin tetas adalah mengkondisikan telur sama seperti telur yang di eramai oleh induknya baik suhu dan kelembaban. Fertilitas adalah kemampuan menghasilkan keturunan dan kesuburan. Pengetesan fertilitas telur adalah suatu hal yang perlu dilakukan. Hal ini terutama diperlukan untuk menentukan jumlah telur yang fertil untuk terus ditetaskan sedangkan yang tidak fertil disingkirkan karena tidak berguna dalam proses penetasan bahkan hanya membuang-buang tenaga dan tempat saja. Padahal tempat yang ada dapat dimanfaatkan untuk telur-telur fertil yang lain atau yang baru akan ditetaskan.

Tes fertilitas semacam ini tidak akan mempengaruhi perkembangan embrio telur, malah sebaliknya kita akan tahu seberapa normal perkembangan embrio didalam telur tersebut telah berkembang atau bertunas. Tetapi tetap sebagai hal yang terpenting dalam proses ini adalah mengetahui seberapa banyak telur yang fertil dan dapat menentukan langkah-langkah yang diperlukan untuk telur yang tidak fertil terutama jika telur-telur tersebut diberikan coretan/tulisan mengenai asal telur dan tanggal ditelurkan oleh induk ayam maupun informasi asal kandangnya. Alat untuk melihat fertilitas telur ini disebut candling. Telur biasanya dilihatsetelah 5-7 hari diinkubasi dalam inkubator. Telur dengan kulit yang putih seperti kulit ayam kampung akan lebih mudah dilihat daripada telur yang warna kulitnya coklat atau warna lainnya. Untuk uji fertilitas, hanya telur yang ada bintik hitam dan jalur darah yang halus yang akan ditetaskan. Telur yang tidak ada perubahan (tetap tidak ada perkembangan) karena mati disingkirkan. Mortalitas adalah jumlah telur yang tidak menetas dari total telur yang fertil. Kematian embrio dapat terjadi karena penetasan yang tidak sesuai seperti: temperatur inkubator terlalau tinggia atau terlalu rendah, penyimpanan telur yang terlalu lama, telur tidak diputar. Telur yang tidak diputar atau dibalik karena kelalaian atau matinya sumber listrik jelas akan mempengaruhi posisi embrio. akibatnya, embrio tidak dapat tumbuh normal atau mengalami kecacatan dan akhirnya mati (Herlina et al., 2016).

Daya tetas merupakan salah satu parameter yang digunakan untuk mengetahui keberhasilan suatu usaha penetasan. Daya tetas adalah persentase jumlah telur yang menetas dari sejumlah telur yang fertil yang ditetaskan. Raharjo (2004) menjelaskan bahwa daya tetas dipengaruhi oleh beberapa paktor yaitu cara penyimpanan, lama penyimpanan, tempat penyimpanan, suhu lingkungan, suhu mesin tetas dan pembalikan selama penetasan. Oleh karena itu, penelitian tentang Pengaruh Suhu Penetasan Terhadap Fertilitas dan Daya Tetas Telur Ayam Kampung (Gallus domesticus) Pada Inkubator ialah untuk mengetahui suhu penetasan terbaik. Adapun tujuan dari penelitian ini ialah untuk mengetahui Pengaruh Suhu Penetasan Terhadap Fertilitas, Mortalitas dan Daya Tetas Telur Ayam Kampung(Gallus domesticus) Pada Inkubator.

\section{METODOLOGI PENELITIAN}

\section{Waktu dan Tempat Penelitian}

Penelitian ini dilaksanakan pada bulan September sampai November 2020, bertempat di Gunung Paok, Desa Perian, Kecamatan Montong Gading, Kabupaten Lombok Timur.

\section{Alat dan Bahan}

Adapun alat-alat yang digunakan dalam penelitian ini yaitu 3 unit mesin tetas otomatis (kapasitas 60 butir telur ayam kampung), Lampu 5 watt 12 buah (masing-masing mesin 3 buah), Termometer 4 buah (masing-masing mesin 1 buah), Higrometer 4 buah (masing-masing mesin 1 buah), Sumber energi listrik, Alat tulis, Senter, Nampan plastik kecil (4 buah) dan Kamera Handpone 
Bahan yang digunakan dalam penelitian ini adalah telur ayam kampung sebanyak 200 butir yang didapatkan dari para peternak yang ada di Dusun Gunung paok Desa Perian Kecamatan Montong Gading Kabupaten Lombok Timur Nusa Tenggara Barat.

\section{Desain Penelitian}

Penelitian ini menggunakan 150 butir telur ayam kampung yang dibagi menjadi 3 perlakuan dengan suhu yang berbeda-beda dan 5 ulangan dengan jumlah telur perulangan menggunakan 10 butir telur ayam kampung. Perlakuan yang dimaksud adalah:

$$
\begin{aligned}
& \mathrm{P} 1=\text { Dengan suhu } 35^{\circ} \mathrm{C}-36^{\circ} \mathrm{C} \\
& \mathrm{P} 2=\text { Dengan suhu } 37^{\circ} \mathrm{C}-38^{\circ} \mathrm{C} \\
& \mathrm{P} 3=\text { Dengan suhu } 39^{\circ} \mathrm{C}-40^{\circ} \mathrm{C}
\end{aligned}
$$

Setiap satu siklus penetasan dihitung satu ulangan yaitu selama 21-22 hari. Telur tetas yang digunakan dalam penelitian ini adalah telur ayam kampung yang dipelihara secara umbaran oleh para peternak yang ada di Dusun Gunung Paok.

\section{Parameter Penelitian}

1. Fertilitas

Fertilitas didapatkan dengan menghitung jumlah telur yang fertil dari jumlah telur sampel dengan rumus:

\section{Fertilitas $=\underline{\text { Jumlah telur yang fertil }} \times 100 \%$ Jumlah telur yang masuk}

2. Mortalitas

Mortalitas didapatkan dengan menghitung jumlah embrio yang mati dari jumlah telur yang fertil dengan rumus :

\section{Mortalitas $=$ Jumlah kematian embrio $\times 100 \%$ Jumlah telur yang fertile}

3. Daya Tetas

Daya tetas didapatkan dengan menghitung jumlah telur yang berhasil menetas dari jumlah telur yang fertil dengan rumus :

\section{Daya tetas $=\underline{\text { Jumlah telur yang menetas }} \times 100 \%$ Jumlah telur yang fertile}

\section{Analisa Data}

Analisis data dilakukan dengan Analysis of Variance (ANOVA). Apabila terdapat perbedaan yang nyata (significant) pada perlakuan akan dilanjutkan dengan uji Beda Nyata Terkecil (BNT).

\section{HASIL DAN PEMBAHASAN}

Hasil analisis data fertilitas, mortalitas dan daya tetas telur ayam kampung dengan suhu yang berbedabeda pada inkubator dapat dilihat pada Tabel 1 .

Tabel 1. Fertilitas, Mortalitas dan Daya Tetas Telur Ayam Kampung pada inkubator

\begin{tabular}{lccc}
\hline \multirow{2}{*}{ Parameter } & \multicolumn{3}{c}{ Perlakuan } \\
\cline { 2 - 4 } & $84 \pm 5,47^{\mathrm{a}}$ & P2 & P3 \\
\hline Fertilitas (\%) & $16 \pm 4,89^{\mathrm{a}}$ & $6 \pm 4,47^{\mathrm{c}}$ & $92 \pm 4,47^{\mathrm{b}}$ \\
\hline Mortalitas (\%) & $44,99 \pm 7,05^{\mathrm{a}}$ & $82,88 \pm 8,87^{\mathrm{c}}$ & $8 \pm 4^{\mathrm{b}}$ \\
\hline Daya Tetas (\%) & abc & Superskrip yang berbeda pada & baris yang sama menunjukan perbedaan \\
\hline Keterangan : & yang nyata $(\mathrm{p}<0.05)$. & &
\end{tabular}




\section{Fertilitas}

Hasil analisa sidik ragam menunjukkan bahwa perbedaan suhu telur ayam kampung pada inkubator menunjukkan perbedaan yang nyata terhadap $(\mathrm{P}>0,05)$ fertilitas. Fertilitas telur ayam kampung paling tinggi diperoleh pada suhu (P2) yaitu $94 \pm 5,47 \%$, sedangkan fertilitas telur ayam kampung paling rendah diperoleh pada suhu (P1) yaitu $84 \pm 5,47 \%$.Fertilitas ayam kampung pada P3 diperoleh yaitu $92 \pm$ $4,47 \%$.

Fertilitas telur ayam kampung menurut beberapa literatur dipengaruhi oleh beberapa faktor yaitusperma, pakan, umur pembibit, musim atau suhu, sifat kawin pejantan, waktu perkawinan dan produksi telur (Agromedia et al., 2002). Ditambahkan oleh King'ori (2011) bahwa faktor yang mempengaruhi fertilitas antara lain adalah nutrien, motilitas sperma, dan persentase sel sperma yang abnormal atau mati. Fertilitas merupakan persentase dari telur-telur yang memperlihatkan adanya perkembangan atau pertumbuhan embrio dari sejumlah telur yang akan ditetaskan tanpa memperhatikan telur tersebut menetas atau tidak (Sinabutar et al., 2009). Fertilitas telur diperoleh setelah terjadi proses pembuahan yaitu penggabungan antara sel sperma jantan dan sel telur betina. Fertilitas pada telur baru dapat diketahui pada hari ke-4 atau hari ke-5 setelah dimulai pengeraman dan merupakan waktu yang ideal untuk melakukan peneropongan (candling) pada telur. Pada dasarnya ciri dari telur untuk semua unggas yang memiliki embrio atau tidak itu sama yaitu adanya titik hitam gelap didalam isi telur dan rongga udara telu terlihat dengan jelas. Jika embrio telah tumbuh maka akan mulai terlihat serabutserabut merah yang merupakan pembuluh darah disekitar titik tersebut dan akan semakin banyak seiring berjalannya waktu. Telur fertil dan infertil dapat dilihat pada peneropongan (candling) Gambar 1. dan Gambar 2. berikut.

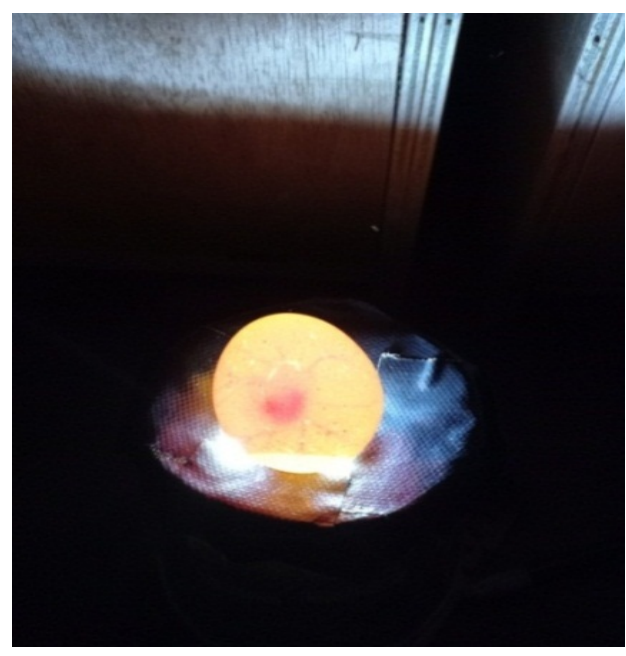

Gambar 1. Telur fertil

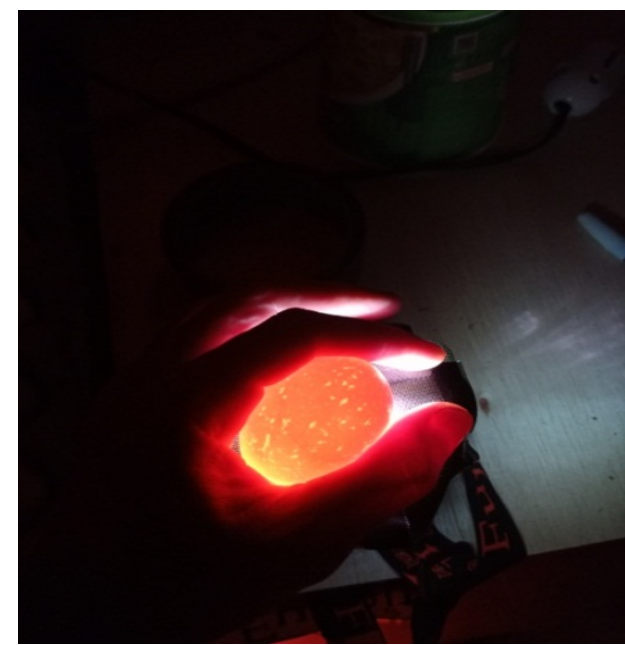

Gambar 2. Telur infertil

Gambar 1 dan gambar 2. menunjukan adanya perbedaan antara telur fertil dan telur infertil. Telur fertil menunjukan perkembangan dengan adanya gumpalan darah dan meluasnya urat-urat darah, sedangkan telur infertil terlihat terang dan bening tanpa garis, rongga udara tidak terlihat jelas karena disebabkan tidak terjadinya perkembangan pada telur walaupun dimasukkan ke dalam inkubator.

\section{Mortalitas}

Suhu dan kelembaban merupakan faktor penting untuk perkembangan embrio. Suhu yang terlalu rendah ataupun terlalu tinggi akan menyebabkan kematian embrio ataupun abnormalitas embrio.

Tabel 1. menunjukkan bahwa mortalitas berbeda nyata pada kematian embrio $(\mathrm{P}>0.05)$. Kematian embrio tertinggi diperoleh pada suhu (P1) yaitu $16 \pm 4,89 \%$ sedangkan kematian embrio paling rendah diperoleh pada suhu (P2) yaitu $6 \pm 6,49 \%$. Kematian embrio telur ayam kampung pada $\mathrm{P} 3$ diperoleh ratarata yaitu $8 \pm 4 \%$. Semakin kecil angka kematian pada telur ayam kampung maka akan semakin baik.

Penurunan daya tetas dapat disebabkan karena tingginya kematian embrio dini. Kematian embrio tidak terjadi secara merata selama masa pengeraman telur. Sekitar 60 persen kematian embrio terjadi pada dua fase. Pada fase awal, puncak kematian embrio terjadi pada hari ke-4, fase akhir puncak terjadi 
pada hari ke-14. Kematian embrio dini meningkat antara hari ke-2, dan ke-4 masa pengeraman (Saefuddin, 2000). Kematian embrio telur ayam kampung dapat dilihat pada peneropongan (candlling) Gambar 3 dan 4.

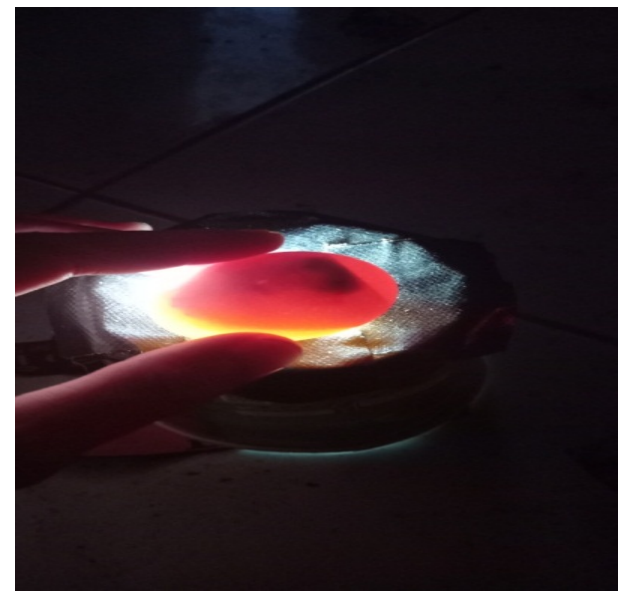

Gambar 3. Embrio mati

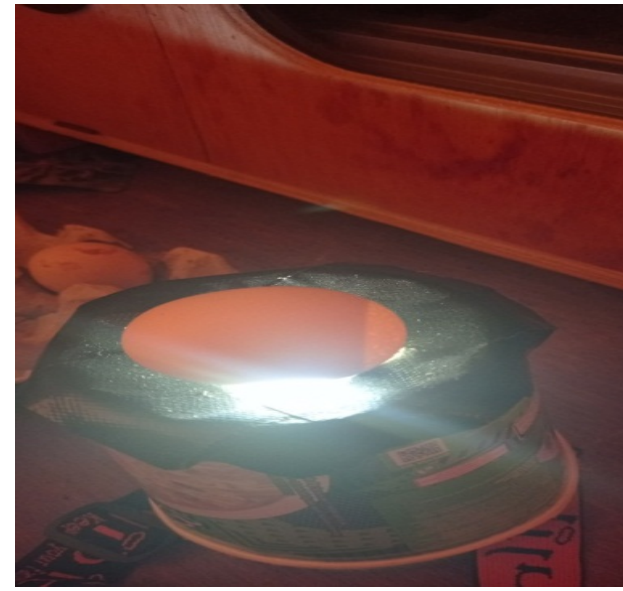

Gambar 4.Embrio hidup

\section{Daya Tetas}

Persentase telur yang menetas dari jumlah telur yang fertil disebut daya tetas (Card and Ellsworth, 1993). Daya tetas dapat digunakan sebagai parameter keberhasilan dari usaha penetasan telur ayam kampung. Semakin tinggi daya tetas yang diperoleh maka keuntungan usaha penetasan akan semakin tinggi, sedangkan daya tetas yang rendah akan menyebabkan keuntungan yang diperoleh semakin kecil. Menurut North dan Bell (1990) semakin tinggi jumlah telur yang fertil dari sejumlah telur yang ditetaskan akan dihasilkan persentase daya tetas yang tinggi, namun fertilitas telur yang tinggi tidak selalu mengakibatkan daya tetas yang tinggi juga, karena selain fertilitas daya tetas juga dipengaruhi oleh kualitas telur. Banyak faktor yang mempengaruhi daya tetas telur, cara atau metode penyimpanan, pengaturan suhu dan kelembaban inkubator, kebersihan telur, pengumpulan dan penyimpanan telur (Nazirah et al., 2014). Ditambahkan oleh Sutiyono (2006) menyatakan bahwa daya tetas telur dipengaruhi oleh penyimpanan telur, faktor genetik, suhu dan kelembaban, umur induk, kebersihan telur, ukuran telur, nutrisi dan fertilitas telur. King'ori (2011) mengemukakan bahwa ada beberapa hal yang mempengaruhi gagalnya telur fertil untuk menetas, faktor tersebut diantaranya adalah nutrien di dalam telur dan kondisi yang tidak memungkinkan untuk perkembangan embrio.

Menurut Yoshizaki dan Saito (2002) banyak faktor yang dapat mengganggukeberhasilan inkubasi atau kualitas anak ayam yang menetas, seperti posisi telurdan pembalikan selama inkubasi. Sebagian besar telur ayam kampung perludiputar selama inkubasi agar perkembangan embrionya menjadi normal.

Tabel 1. menunjukan hasil analisis bahwa terdapat perbedaan yang nyata pada daya tetas yang disebabkan oleh perbedaan suhu dalam inkubator $(\mathrm{P}>0,05)$. Hasil terbaik diperoleh padasuhu $37^{\circ} \mathrm{C}-$ $38^{\circ} \mathrm{C}(\mathrm{P} 2)$ dengan rata-rata daya tetas $82,88 \pm 8,87 \%$, sedangkan daya tetas yang paling rendah diperoleh suhu paling rendah $35^{\circ} \mathrm{C}-36^{\circ} \mathrm{C}(\mathrm{P} 1)$ dengan rata-rata daya tetas $44,99 \pm 7,05 \%$. Daya tetas pada $\mathrm{P} 3$ (dengan suhu $39^{\circ} \mathrm{C}-40^{\circ} \mathrm{C}$ ) adalah $58,88 \pm 6,66 \%$. Periode inkubasi dengan suhu terlalu rendah atau dibawah suhu optimal saat penetasan mengakibatkan embrio sensitif pada pertumbuhan dan perkembangannya sehingga kesulitan menetas.

Daya tetas kurang optimal yang dihasilkan pada suhu inkubasi erat kaitannya dengan penyusutan bobot telur akibat pengaturan suhu. Semakin tinggi suhu maka semakin besar susut telur sehingga mengalami pengeluaran panas yang lebih besar melalui evaporasi dan sangat besar kemungkinan embrio gagal menetas akibat dehidrasi karena penguapan besar, sebaliknya semakin rendah suhu maka susut tetas semakin kecil memungkinkan embrio tidak bermetabolisme dan menyebabkan embrio gagal menetas. Penyusutan telur terjadi karena penguapan gas-gas dan cairan yang berada dalam telur menyebabkan bobot telur menurun. Cairan dalam telur berfungsi melarutkan zat zat nutrisi untuk pertumbuhan embrio. Penyusutan bobot telur diakibatkan oleh pengaruh suhu dan kelembaban selama periode inkubasi akan menghambat perkembangan embrio yang berdampak pada daya tetas. 


\section{KESIMPULAN}

Pengaruh perbedaan suhu pada inkubator sangat berpengaruh terhadap fertilitas, mortalitas dan daya tetas telur ayam kampung. Hasil terbaik diperoleh pada suhu inkubasi $37^{\circ} \mathrm{C}-38^{\circ} \mathrm{C}(\mathrm{P} 2)$ dengan rata-rata fertilitas $94 \pm 5,47 \%$, mortalitas $6,66 \pm 5,44 \%$ dan daya tetas $82,88 \pm 8,87 \%$.

\section{DAFTAR PUSTAKA}

Agromedia. 2002. Puyuh Si Mungil yang Penuh Potensi. Agromedia Pustaka. Jakarta.

Badan Pusat Statistik. 2019. Rata-rata Harian Konsumsi Protein Perkapitadan Konsumsi Kalori Perkapita Tahun 1990 2018. https://www.bps.go.id/statictable /2018/01/11/1986/rata-rata-hariankonsumsi protein-per-kapita-dan-konsumsi-kalori-per-kapita-tahun-1990---2018.html(diakses pada tanggal 10 September 2020).

Card, L.E. and L. Ellsworth. 1993. Poultry Production. Lea and Febiger, Philadelphia.

Herlina, B., T. Karyono, R. Novita, P. Novantoro. 2016. Pengaruh lama Penyimpanan Telur Ayam Merawang (Gallus Gallus) Terhadap Daya Tetas.Jurnal Sains Peternakan Indonesia. 11 (1): 4857.

King' ori, A.M. 2011. Review of the factors that influence egg fertility and hatchability in Poultry. Int. J. Poult. Sci. 10: 483-492.

Nazirah. 2014. Pengaruh Lama Penyimpanan Telur Puyuh (Coturnix coturnix japonica) terhadap Daya Tetas dan Berat Telur. Skripsi. Fakultas Kegiatan dan Ilmu Pendidikan. Universitas Syiah Kuala Darussalam.Banda Aceh.

North, N.O. and D.D. Bell. 1990. Commercial Chicken Production Manual. Fourth Edition. New York University of California Poultry Specialist.

Raharjo, P. 2004. Ayam Buras. Agromedia. Yogyakarta.

Sutiyono, S. Riyadi, S. Kismiati. 2006. Fertilitas dan Daya Tetas Telur dari Ayam Petelur Hasil Inseminasi Buatan Menggunakan Semen Ayam yang Diencerkan dengan Bahan Berbeda. Skripsi. Fakultas Peternakan Universitas Diponegoro. Semarang.

Sinabutar, M. 2009. Pengaruh frekuensi inseminasi buatan terhadap daya tetas telur itik lokal yang di inseminasi buatan dengan semen entok. Skripsi. Fakultas Pertanian Universitas Sumatra Utara. Medan.

Yoshizaki, N. and H. Saito. 2002. Changes in shell membranes during the development of quail embryos. Poult. Sci. 81: 246-251. 